Original Article

\title{
Feasibility in seed germination of Hypericum perforatum L. submitted at different temperatures and treatments with high dilutions
}

\author{
Aline Nunes ${ }^{1 *}$, Simone Silmara Werner ${ }^{2}$, Mari Inês Carissimi Boff ${ }^{3}$, Pedro Boff ${ }^{2,4}$ \\ 1 - Universidade Federal de Santa Catarina, Florianópolis, Brasil \\ 2 - Epagri, Lages, Brasil \\ 3 - Universidade do Estado de Santa Catarina, Lages, Brasil \\ 4 - Universidade do Planalto Catarinense, Lages, Brasil \\ *Correspondence author: alinenunes_bio@hotmail.com
}

\begin{abstract}
Background Hypericum perforatum is used as a medicinal plant, mostly in antidepressant treatment. With endogenous and exogenous dormancy, more studies about the germination of the seeds are necessary. Aim: To evaluate the effect of temperature and of preparations of high dilutions on the germination of seeds of Hypericum perforatum. Methods Three bioassays were carried out in chambers of germination, using a completely randomized experimental design and in duplicate. In the first bioassay, of temperatures of 20,25 and $30{ }^{\circ} \mathrm{C}$ was evaluated, with 20 replicates and 50 seeds in each replicate. In the second, the effect of high dilutions (Kali carbonicum, Natrum muriaticum, Phosphorus and Silicea terra in $12 \mathrm{cH}$ ) using 4 replicates with 50 seeds each. In the third, Kali carbonicum was tested at $6,12,20,30 \mathrm{cH}$ with 50 seeds and 4 replicates. The percentage of germination, germination rate index (GRI), average germination time (AGT) and seedlings with cotyledons. The data were analyzed through the $\mathrm{R}$ software at a $5 \%$ significance. Results At the temperature of $25{ }^{\circ} \mathrm{C}, 63 \%$ of the seeds germinated while at the temperatures of 20 and $30{ }^{\circ} \mathrm{C}$ the percentage was $26 \%$ and $18 \%$, respectively. In seeds treated with Kali carbonicum $12 \mathrm{cH}$ the germination rate increased significantly in relation to the control group. Kali carbonicum $6 \mathrm{cH}$ increased the GRI of the seeds, while at $20 \mathrm{cH}$, it increased the AGT, showing delay in germination. Conclusion The use of the Kali carbonicum assists in the breakage of dormancy and average time of germination in Hypericum perforatum seeds.
\end{abstract}

Keywords: St. John's Wort; homeopathy; medicinal plants.

\section{Introduction}

Hypericum perforatum is a medicinal species known as St. John's Wort. It has been extensively studied and used in antidepressant, antitumoral and antioxidant treatments [1]. Extracts from this plant present cytoprotective, neurotrophic and anti-inflammatory action and the use of it has provided similar results to those of conventional drugs commonly prescribed for depression, such as fluoxetine (fluoxetine hydrochloride) and Cannabis, which is illegal in Brazil [2-4].

Plants of the genus Hypericum predominate in subtropical regions [5]. In Brazil, there are 22 native species of the genus Hypericum. However, Hypericum perforatum is not included in this group [6]. 
The species H. perforatum is native to Europe, Asia and North Africa; it grows and develops on nutrient-poor, sandy, arid and rocky soils, and it can be easily found in pasture, roadside, and humandisturbed environments [7,8]. In Brazil, H. perforatum cannot become naturalized, as it does not reach the appropriate size to bloom, thus requiring adequate interventional practices [9]. Likewise, the recommendations for overcoming seed dormancy have not shown satisfactory results [10,11].

H. perforatum seedlings are delicate and sensitive to climate and soil changes [12]. Seed germination and growth of $H$. perforatum plants are influenced by temperature, luminosity and substrate [13]. Among environmental factors, temperature should be particularly taken into consideration because it has a strong effect on germination percentage and vigor determination of seedlings [14]. According to the Seed Analysis Rules for seed germination, the temperature of $20^{\circ} \mathrm{C}$ or alternatively $20-30^{\circ} \mathrm{C}$ are recommended [15]. Seeds of the genus Hypericum present low germinative capacity, because chemical inhibition of the exudate present in the seed capsule causes endogenous and exogenous dormancy [16, 12]. In this way, the use of germination facilitators - such as adequate temperature/photoperiod and seed treatment - has been recommended for improvement of the initial starter and establishment of seedlings [13].

For cultivation of medicinal plants, multiplication protocols must be followed to ensure integrity of phytomedicine metabolites, as provided by law. In this sense, the use of high dynamic dilutions introduces the perspective of non-residual management of medicinal plants, thereby maintaining their photochemical attributes [17]. The use of preparations at high dilutions in plants is widely supported by the literature, with positive responses in phytotherapeutic performance and improvement of photochemical attributes of medicinal plants [18,19].

The aim of this work was to evaluate the effects of temperature and high dilution preparations on germination of Hypericum perforatum seeds in the laboratory.

\section{Material and Methods}

The research was conducted between August 2017 and January 2018, in the Laboratory of Plant Health and Homeopathy, at the Experimental Station of EPAGRI, located in Lages, Santa Catarina state, Brazil. The seeds of Hypericum perforatum were purchased in an agricultural supply store (Feltrin Sementes®) and had a shelf life until 2020 and 64\% germination.

In all experiments, the seeds were arranged in polystyrene boxes ( 11 x 11 x 3.5 in height) (Gerbox®). The study was carried out in three stages. In the first stage, the ideal temperature for germination of the $H$. perforatum seeds was tested. Evaluations were respectively made of the effect of different homeopathic preparations (high dilutions), in the second stage, and of the effect of different hahnemannian centesimal scales $(\mathrm{cH})$ of the Kali carbonicum preparation, in the third stage.

\section{Germination tests of seeds under different temperatures}

In the laboratory, temperatures of 20,25 and $30^{\circ} \mathrm{C}$ were tested with 20 replicates of 50 seeds each. The assays were conducted in BOD growth chambers (Oxilab Development ${ }^{\circledR}$ ). The seeds were placed 
on Germitest ${ }^{\circledR}$ paper and moistened with distilled water at 2.5 times the dry paper weight $(\mathrm{g})$. Evaluations began seven days after experiment implementation. The following parameters were evaluated: germination percentage, germination rate index (GRI), average germination time (AGT) and seedlings with cotyledons. The germinated seeds were counted daily, from the seventh day of the experiment to the 19 th day.

\section{Preparation of solutions}

The homeopathic preparations were purchased in a homeopathic pharmacy in the $6 \mathrm{cH}$ matrix dynamization (sixth order of hahnemannian centesimal dilution). The procedures determined by the Brazilian Homeopathic Pharmacopeia [20] were followed. The solution was prepared at 10cH using $70 \%$ alcohol as an inert material. To obtain $11 \mathrm{cH}$ and $12 \mathrm{cH}$, the solution was diluted and dynamized with distilled water.

The solutions were selected on the basis of the repertorial language correlated with the main characteristics presented by Hypericum perforatum in consultation with the medical material, such as: sensitivity to cold, need for constant water and light, photosensitivity, fragility and low germinative capacity. The preparations Kali carbonicum, Natrum muriaticum, Phosphorus and Silicea terra were selected after repertorization.

\section{Germination test of seeds under different homeopathic preparations}

The optimal temperature established in the first bioassay was used to conduct the next test. The treatments consisted of those preparations with high dilutions of Kali carbonicum, Natrum muriaticum, Phosphorus and Silicea terra in $12 \mathrm{cH}$ and distilled water (not dynamized) as a control treatment. The seeds of each treatment were immersed for 15 minutes in $20 \mathrm{ml}$ of the respective homeopathic preparation. Subsequently, the treated seeds were placed on Germitest $\AA^{\circledR}$ paper moistened with distilled water at 2.5 times the dry paper weight (g). For each treatment, 4 replicates were made, consisting of Gerbox ${ }^{\circledR}$ containing 50 seeds of $H$. perforatum each. Afterwards, the boxes containing the treated seeds were placed in trays and enclosed in plastic bags, to isolate each treatment and maintain relative humidity at saturation inside the trays. The trays containing the Gerbox ${ }^{\circledR}$ boxes were transferred into the BOD germination chamber, with the temperature set at $25^{\circ} \mathrm{C}$. The assay was performed in duplicate. The double-blind methodology was used; therefore, the analyst did not know which tray contained which treatment, as they were identified by codes. Evaluations of GRI, AGT and number of germinated seeds started on the seventh day after seed treatment and lasted until the 18th day.

Germination test of seeds under the Kali carbonicum preparation

Seeds of $H$. perforatum were treated with four different potencies $(6,12,20$ and $30 \mathrm{cH})$ of the homeopathic preparation Kali carbonicum. Unmodified distilled water was used as a control treatment. The homeopathic preparation Kali carbonicum was purchased in a compounding 
pharmacy at $4 \mathrm{cH}$ in $70 \%$ alcohol. As described above, the dilutions and dynamizations of each respective potency (treatment) were performed with addition of inert water. The seeds of each treatment were immersed for 15 minutes in $20 \mathrm{ml}$ of each potency. Subsequently, the seeds were placed in Gerbox $\AA$ boxes on Germitest ${ }^{\circledR}$ paper moistened with distilled water at 2.5 times the dry paper weight $(\mathrm{g})$, with 4 replicates containing 50 seeds each. After seed distribution, the Gerbox® boxes were placed in trays sealed with plastic bags to isolate each treatment and maintain relative humidity at saturation. The trays containing the Gerbox ${ }^{\circledR}$ boxes were transferred into the BOD germination chamber, with the temperature set at $25^{\circ} \mathrm{C}$. The assay was performed in duplicate. Evaluations of GRI, AGT and counts of germinated seeds started on the seventh day after seed treatment and lasted until the 18th day.

\section{Statistical analysis}

Data from both trials (duplicate) were analyzed together, including the interaction effect between treatments and trial in the model. In order to calculate the germination rate index (GRI), the model proposed by Maguire (1962) was applied, with: GRI= (G1/N1) + (G2/N2 ... + (Gn/Nn), where: G1, G2, $\mathrm{Gn}=$ number of seedlings germinated in the first, second, up to the last count, and N1, N2, Nn = number of weeks from the first, second, up to the last count.

To determine average germination time (AGT), the calculation of Labouriau (1983) was used: AGT = $\sum$ ni.ti $\sum$ ni, where: $n i=$ number of seeds germinated at a time interval, and $\mathrm{ti}=$ time interval of germination.

Data analysis was conducted using the F-test, and assumptions of homoscedasticity (Bartlett test) and normality (Shapiro-Wilk test) were checked. In cases where the assumptions of the model were not met, the transformation proposed by Box-Cox was applied, using the optimal lambda for transformation. When there was a significant effect of the treatments, the comparison of means was carried out by using Tukey's test. The binomial model with dispersion parameter (quasibinomial) and probit link function was used to analyze the germination data over time, collected in the test with different preparations at high dilutions. Analysis of all data was performed using the R environment and considering a 5\% significance level [21].

\section{Results}

Germination tests of seeds under different temperatures

Germination percentage, number of seedlings with cotyledons and average germination time (AGT) were higher at $25^{\circ} \mathrm{C}$, compared to temperatures of $20 \mathrm{oC}$ and $30^{\circ} \mathrm{C}$ (Table 1 ). The germination rate index (GRI) of $H$. perforatum seeds under a temperature of $20^{\circ} \mathrm{C}$ (16.84 days) was significantly higher than those submitted to temperatures of $25^{\circ} \mathrm{C}(14.39$ days $)$ and $30^{\circ} \mathrm{C}(15.06$ days). Temperatures of $25^{\circ} \mathrm{C}$ and $30^{\circ} \mathrm{C}$ did not differ among each other (Table 1). Temperatures of 20 and $30^{\circ} \mathrm{C}$ resulted in significantly fewer seedlings with cotyledons, and similar results were found for germination percentage and germination velocity, when compared to the temperature of $25^{\circ} \mathrm{C}$. 
Table 1 - Germination (\%), average germination time (AGT), germination rate index (GRI) and seedlings with cotyledons from Hypericum perforatum seeds submitted to different temperatures in the laboratory. Lages/SC, 2018.

\begin{tabular}{|c|c|c|c|c|}
\hline $\begin{array}{c}\text { Temperatures } \\
\left({ }^{\circ} \mathrm{C}\right)\end{array}$ & $\begin{array}{c}\text { Germination } \\
(\%)\end{array}$ & AGT & $\begin{array}{c}\text { GRI } \\
\text { (days) }\end{array}$ & $\begin{array}{c}\text { Seedlings with } \\
\text { cotyledons (No.) }\end{array}$ \\
\hline 20 & $26 \pm 3.51 \mathrm{~b}$ & $3.75 \pm 0.58 \mathrm{~b}$ & $16.84 \pm 0.12 \mathrm{a}$ & $7.41 \pm 1.21 \mathrm{~b}$ \\
\hline 25 & $63 \pm 2.10 \mathrm{a}$ & $20.59 \pm 0.84 \mathrm{a}$ & $14.39 \pm 0.04 \mathrm{~b}$ & $26.01 \pm 1.06 \mathrm{a}$ \\
\hline 30 & $18 \pm 2.90 \mathrm{~b}$ & $3.94 \pm 0.79 \mathrm{~b}$ & $15.06 \pm 0.82 \mathrm{~b}$ & $7.16 \pm 1.41 \mathrm{~b}$ \\
\hline
\end{tabular}

* Means followed by the same letter in the column do not differ significantly from one another by Tukey's test ( $5 \%$ significance). \pm Standard error.

H. perforatum seeds are extremely small $(0.12 \mathrm{~g}$ equivalent to 1000 seeds) and fragile; therefore, manipulation is difficult and they are easily lost. Seed germination started on the 7th day of the experiment after dormancy breaking. With the advent of dormancy breaking, the hypocotyl began to grow, concomitantly with the radicle. Both structures are fragile and slow growing; thus, they require special care to avoid damage. With the increase of radicle size, formation of secondary roots started on the 13th day (Figure 1).
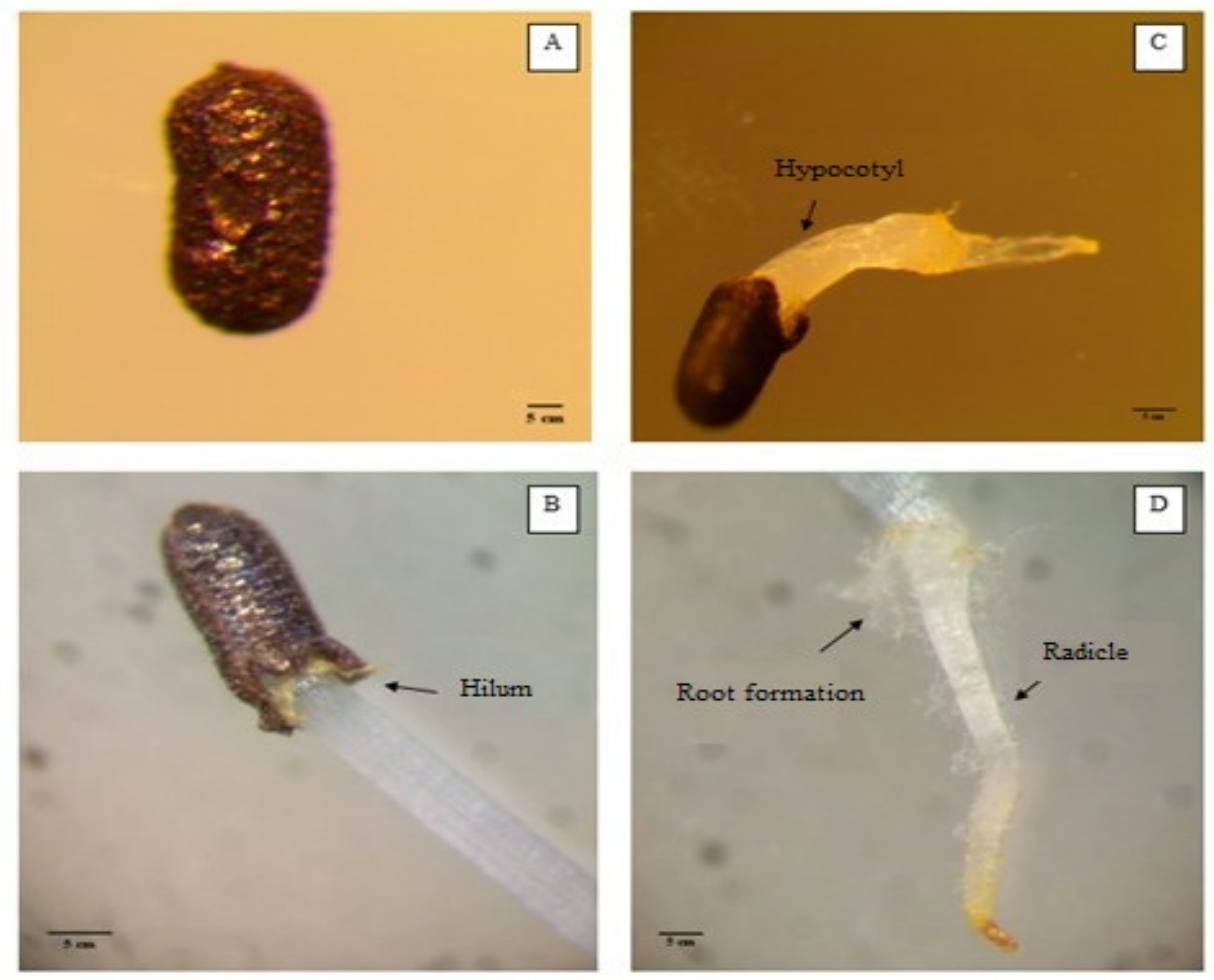

Figure 1 - Hypericum perforatum - seed structures during the germination process. A) seed; B) Hilum rupture; C) Hypocotyl emergence; D) Radical and secondary root formation.

Source: Prepared by the authors, 2018. 
In this study, the temperature of $25^{\circ} \mathrm{C}$ was the best condition found for the increase of cotyledons, reflecting on a higher rate in the establishment of structures (Table 1).

Germination test of seeds under different homeopathic preparations

The homeopathic preparation Kali carbonicum had a positive effect on seed germination percentage of $H$. perforatum, which was $70.75 \%$ after 18 days. The start of seed germination was promising with the Kali carbonicum preparation and remained at a good rate during the whole germination time. The homeopathic preparation Natrum muriaticum (63.50\%) did not differ from the control treatment $(62.75 \%)$ for germination percentage but differed from Phosphorus $(61.00 \%)$ and Silicea terra (61.25\%) (Figure 2).

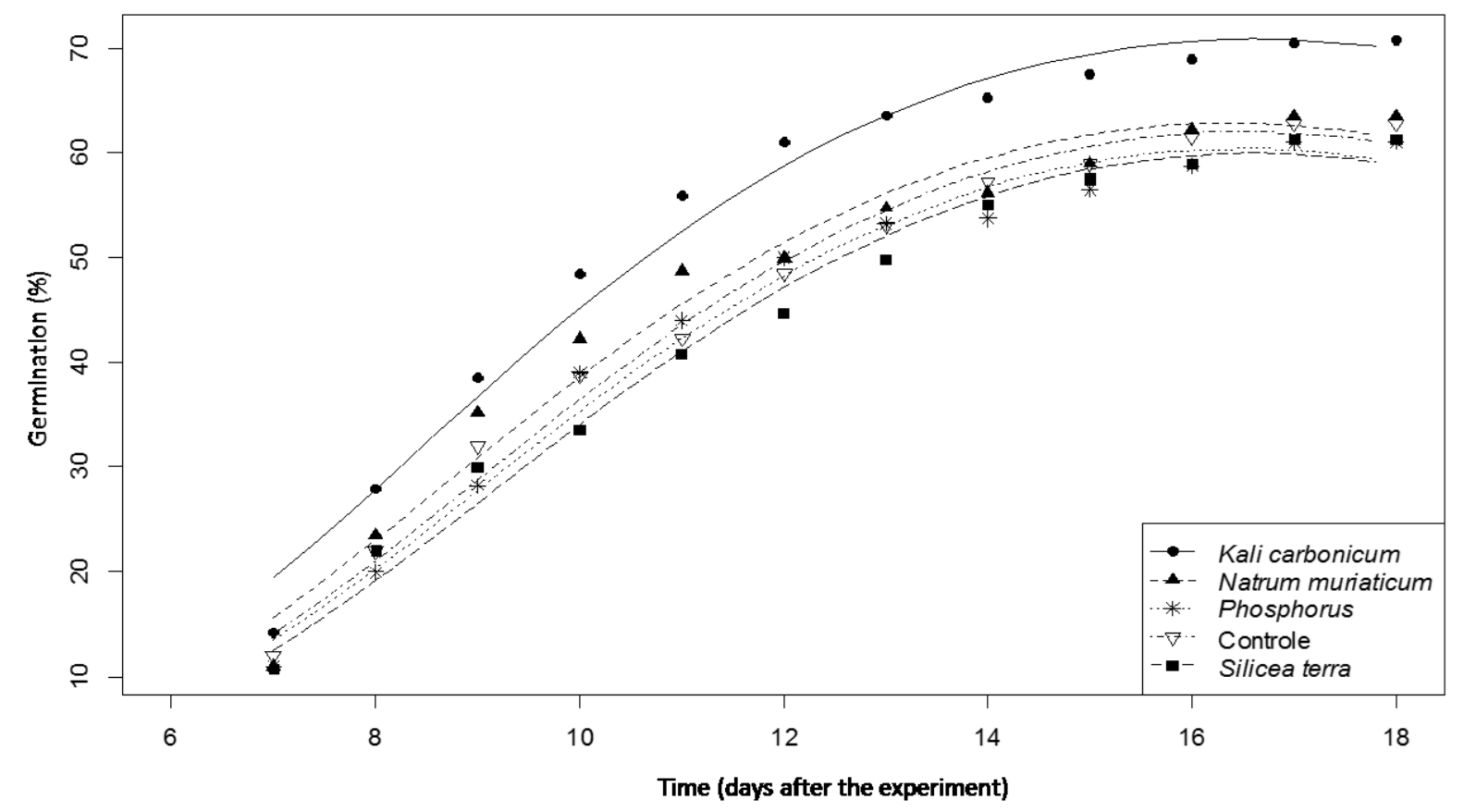

Figure 2 - Germination percentage of Hypericum perforatum seeds under different homeopathic preparations in $12 \mathrm{cH}$ dynamization.

Source: Prepared by the authors, 2018.

Kali carbonicum did not differ from the treatments Natrum muriaticum and the control treatment with distilled water for the GRI variable; however, it differed from Phosphorus and Silicea terra, which presented lower rates. For the AGT variable, the treatments did not present a statistically significant effect (Table 2).

For number of seedlings with cotyledons, experiments one and two showed interaction with the treatment; in this way, the data are separated into two columns. In experiment one, the Natrum muriaticum treatment differed from the control treatment; however, it did not differ from the other treatments. In the other treatments, there was no difference compared to the control treatment. In experiment two, none of the treatments showed greater efficiency in the establishment of cotyledons. 
Table 2 - Germination rate index (GRI), average germination time (AGT) and seedlings with cotyledons from Hypericum perforatum seeds submitted to treatment with different homeopathic preparations in $12 \mathrm{cH}$. Lages/SC, 2018.

\begin{tabular}{|l|c|c|c|c|}
\hline \multicolumn{1}{|c|}{ Treatment } & GRI & $\begin{array}{c}\text { AGT } \\
\text { (days) }\end{array}$ & $\begin{array}{c}\text { Seedling with } \\
\text { cotyledons }^{1}\end{array}$ & $\begin{array}{c}\text { Seedling with } \\
\text { cotyledons }^{2}\end{array}$ \\
\hline Kali-c & $25.64 \pm 0.73 \mathrm{a}$ & $13.53 \pm 0.06 \mathrm{~ns}$ & $13.25 \pm 2.56 \mathrm{ab}$ & $8.25 \pm 0.48 \mathrm{~ns}$ \\
\hline Nat-m & $22.28 \pm 0.95 \mathrm{ab}$ & $13.59 \pm 0.06$ & $14.00 \pm 0.56 \mathrm{a}$ & $3.50 \pm 1.19$ \\
\hline Phos & $20.81 \pm 1.22 \mathrm{~b}$ & $13.67 \pm 0.03$ & $9.00 \pm 0.71 \mathrm{ab}$ & $4.25 \pm 0.48$ \\
\hline Sil & $20.34 \pm 1.40 \mathrm{~b}$ & $13.72 \pm 0.08$ & $10.50 \pm 3.23 \mathrm{ab}$ & $5.25 \pm 1.65$ \\
\hline Control & $21.45 \pm 0.72 \mathrm{ab}$ & $13.67 \pm 0.05$ & $5.00 \pm 0.82 \mathrm{~b}$ & $6.00 \pm 1.00$ \\
\hline
\end{tabular}

*Means followed by the same letter in the column do not differ significantly from one another in Tukey's test (5\% significance). \pm Standard error. Kali-c $=$ Kali carbonicum; Nat-m $=$ Natrum muriaticum; Phos = Phosphorus; Sil = Silica terra; Control = distilled water. ${ }^{1}$ Bioassay $1 .{ }^{2}$ Bioassay 2. For the variables GRI and AGT, the interaction between treatments and experiment was not significant. $n s=$ not significant.

Germination test of seeds under the Kali carbonicum preparation

The homeopathic preparation Kali carbonicum in the different hahnemannian centesimals showed no difference on germination percentage of Hypericum perforatum seeds. For the GRI variable, the Kali carbonicum in $6 \mathrm{cH}$ was higher than $20 \mathrm{cH}$, but it did not differ from the other treatments. For the AGT variable, the preparation at $20 \mathrm{cH}$ was superior to the others, showing delay in the germination of Hypericum seeds (Table 3).

Table 3 - Influence of the different orders of hahnemannian centesimal dilution ( $\mathrm{cH})$ of the Kali carbonicum homeopathic preparation on germination (\%), germination rate index (GRI) and average germination time (AGT) of Hypericum perforatum seeds. Lages/SC, 2018.

\begin{tabular}{|l|c|c|c|}
\hline \multicolumn{1}{|c|}{ Treatment } & $\begin{array}{c}\text { Germination } \\
(\%)\end{array}$ & GRI & $\begin{array}{c}\text { AGT } \\
\text { (days) }\end{array}$ \\
\hline Kali carbonicum 6CH & $71 \pm 2.50 \mathrm{~ns}$ & $21.44 \pm 0.90 \mathrm{a}$ & $13.79 \pm 0.03 \mathrm{~b}$ \\
\hline Kali carbonicum 12CH & $68 \pm 3.37$ & $19.76 \pm 1.09 \mathrm{ab}$ & $13.94 \pm 0.06 \mathrm{~b}$ \\
\hline Kali carbonicum 20CH & $64 \pm 3.40$ & $14.95 \pm 1.11 \mathrm{~b}$ & $14.59 \pm 0.09 \mathrm{a}$ \\
\hline Kali carbonicum 30CH & $65 \pm 2.08$ & $17.63 \pm 0.64 \mathrm{ab}$ & $14.12 \pm 0.05 \mathrm{~b}$ \\
\hline Control & $64 \pm 2.21$ & $18.10 \pm 2.08 \mathrm{ab}$ & $13.95 \pm 0.18 \mathrm{~b}$ \\
\hline
\end{tabular}

*Means followed by the same letter in the column do not differ significantly from one another by Tukey's test (5\% significance). \pm Standard error. For the GRI and AGT variables the interaction between treatments and experiment was not significant. ns $=$ not significant. 
Germination percentage was not altered by the use of the different potencies of $\mathrm{cH}$; however, mean germination time was higher (14.59 days) when Kali carbonicum was used at $20 \mathrm{cH}$, thus interfering in the homogeneity of seed germination and seedling establishment. The germination rate of $\mathrm{H}$. perforatum seeds with Kali carbonicum at $20 \mathrm{cH}(14.95 \%)$ differed significantly from the preparation at $6 \mathrm{cH}(21.44 \%)$.

\section{Discussion}

The temperature data showed that $25^{\circ} \mathrm{C}$ in continuous dark regime is efficient in germinating $H$. perforatum seeds. Tests using temperatures of $20,25,30^{\circ} \mathrm{C}$ and alternating $20-30^{\circ} \mathrm{C}$, with and without photoperiod, achieved better results for alternating temperature and with photoperiods of 16/8 hours [9]. In the results of this research, seeds kept at $25^{\circ} \mathrm{C}$ reached $63 \%$ germination rate, which allows for greater establishment of seedlings. The values found in this research about germination rate show that the optimal temperature was established, considering the maximum germination rate of $64 \%$ informed by the seed seller. It was found that photoperiod variation does not need to be used to for such germination rate to be reached.

H. perforatum seeds are physiologically inactive and very high temperatures could prevent germination [14]. In the experiments carried out, germination started on the 7th day after bioassay setup, and continued until the 18th and 19th day. On the 18th and 19th days, the seedlings presented difficulty in growing, thus requiring adequate substrate to develop. Therefore, as the seeds that had not yet germinated did not show hilum disruption, the experiment was considered to be concluded. The use of homeopathic preparations may interfere with the physiological plant pattern and, therefore, present potential effects of both positive and negative responses [19]. In this study, the treatments in use did not respond in the same way for GRI, which shows that $H$. perforatum plants are sensitive to the use of homeopathic preparations, and their application acts directly on the germinative capacity of the plants. For the results of seed germination percentage, Kali carbonicum is shown to be a high dilution preparation that influences multiple vital functions within the plant, such as increasing nitrogen efficiency and optimizing saline concentration of the cells, because potassium is one of the primary elements in plant nutrition [22].

In the germination test using Kali carbonicum in different $\mathrm{cH}$ values, it was found that the $6 \mathrm{cH}$ treatment differed from the $20 \mathrm{cH}$ treatment for GRI. And for the analysis of AGT, all treatments have shown lower rates compared to the $20 \mathrm{cH}$ treatment. This indicates that among the different indices analyzed for germination and using the same homeopathic preparation, there are positive or negative effects depending on the dilution being used.

These results indicate the action on the wave behavior, where the frequency remains fixed, and variation occurs on the amplitude [23]. In this study, the potency of $6 \mathrm{cH}$ and $30 \mathrm{cH}$ (lower and higher, respectively) did not differ; however, the intermediate dilution $(20 \mathrm{cH})$ was shown to influence germination retardation, indicating nonlinear behavior. 


\section{Conclusion}

The use of high dilutions may reduce dormancy of Hypericum perforatum seeds. Among the treatments used, Kali carbonicum was shown to increase germination rate and to lower germination time.

\section{Acknowledgments}

The FAPESC Project 2015TR1067 and the Support Fund for the Maintenance and Development of Higher Education (FUMDES, in Portuguese), through the Santa Catarina University Scholarship Program UNIEDU.

\section{References}

[1] Brahmac Hari G. Biosynthetic and Total Synthetic Approaches for (+)-Hyperforin. Discovery and Development of Neuroprotective Agents from Natural Products. 2018 [cited 2019 Fev 25]: 435-456. Available from: https://www.sciencedirect.com/science/article/pii/B9780128095935000124

[2] Bonaterra GA, Schwendler A, Hüther J, Schwarzbach H, Schwarz A, Kolb C, Abdel-Aziz H, Kinscherf R. Neurotrophic, Cytoprotective, and Anti-inflammatory Effects of St. John's Wort Extract on Differentiated Mouse Hippocampal HT-22 Neurons. Frontiers in Pharmacology. 2017 [cited 2018 Jan 02]; 8(955): 1-13. Available from: https://www.ncbi.nlm.nih.gov/pubmed/29403374

[3] Hoban CL, Byard RW, Musgrave IF. A comparison of patterns of spontaneous adverse drug reaction reporting with St. John's Wort and fluoxetine during the period 2000-2013. Clinical and Experimental Pharmacology and Physiology. 2015 [cited 2018 Fev 25]; 42: 747751. Available from: https://www.ncbi.nlm.nih.gov/pubmed/25988866

[4] Scherma M, Masia P, Deidda M, Fratta W, Tanda G, Fadda P. New Perspectives on the Use of Cannabis in the Treatment of Psychiatric Disorders. Medicines. 2018 [cited 2019 Fev 15]; 5(4): 1-17. Available from: https://www.ncbi.nlm.nih.gov/pubmed/30279403

[5] Cronquist, A. An integrated system of classification of flowering plants. New York, Columbia University Press, 1981.

[6] Bittrich V, Trad RJ, Cabral FN, Nascimento Júnior JE, Souza VC. Hypericaceae in Lista de Espécies da Flora do Brasil. Jardim Botânico do Rio de Janeiro, 2015. Available from: http://floradobrasil.jbrj.gov.br/jabot/floradobrasil/FB25586

[7] Dehkordi RM, Yadegari M, Hamedi B. Effect of Temperature, Drought and Salinity Stresses on Germination of Portulaca oleracea L., Trigonella foenum-graecium L., Borago officinalis L. 
and Hypericum Perforatum L. Advances in Environmental Biology. 2015 [cited 2018 Abr 20]; 9(4): 148-152. Available

from: http://www.aensiweb.net/AENSIWEB/aeb/aeb March 2015.html

[8] Mossberg B, Stenberg L. Den Nya Nordiska Floran. Norge: Bonnier Fakta; 2010.

[9] Faron MLB, Perecin MB, Lago AA, Bovi OA, Maia NB. Temperatura, nitrato de potássio e fotoperíodo na germinação de sementes de Hypericum perforatum L. e H. brasiliense Choisy. Bragantia. 2004 [cited 2017 Fev 05]; 63(2): 193-199, 2004. Available from: http://www.scielo.br/scielo.php?pid=S0006$87052004000200004 \&$ script=sci_abstract\&tlng=pt

[10] Pérez-García F, Huertas M, Mora E, Peña B, Varela F, González-Benito ME. Hypericum perforatum L. seed germination: interpopulation variation and effect of light, temperature, presowing treatments and seed desiccation. Genetic Resources and Crop Evolution. 2006 [cited 2018 Abr 12]; 53: 1187-1198. Available from: https://link.springer.com/article/10.1007/s10722-005-2012-3

[11] Çirak C, Ayan AK, Keyseroglu K. The Effects of Light and Some Presoaking Treatments on Germination Rate of St. John's Worth (Hypericum perforatum L.) Seeds. Pakistan Journal of Biological Sciences. 2004 [cited 2017 Dez 03]; 7: 182-186. Available from: https://scialert.net/abstract/?doi=pibs.2004.182.186

[12] Çirak C, Kevseroglu V, Ajan AK. Breaking of seed dormancy in Turkish endemic Hypericum species: Hypericum aviculariifolium subsp. depilatum var. depilatum by light and some pre-soaking treatments. Journal of Arid Environments. 2007 [cited $2018 \mathrm{Fev} 12$ ]; 68: 159-164. Available from: https://www.sciencedirect.com/science/article/abs/pii/S014019630600125X

[13] Carvalho NM, Nakagawa J. Sementes: ciência, tecnologia e produção. 5.ed. Jaboticabal: FUNEP, 2012.

[14] Bewley JD, Black M. Seeds: physiology of development and germination. New York: Plenum Press, 1994.

[15] Brasil. Ministério da Agricultura, Pecuária e Abastecimento. Regras para análise de sementes. Brasília, DF: Mapa/ACS. 2009 [cited 2017 Ago 10]. Available from: http://www.agricultura.gov.br/assuntos/insumos-agropecuarios/arquivos-publicacoesinsumos/2946_regras_analise_sementes.pdf

[16] Macchia N, Benvenuti A, Angelini L. Germination characteristics of some seeds of medicinal plants. Rastitel'nye-Resursy. 1983; 21: 461-463. 
[17] Capra RS, Gratão AS, Freitas GB, Leite MN. Preparados homeopáticos e ambiente de cultivo na produção e rendimento de quercetina em carqueja [Baccharis trimera (Less) DC.]. Revista Brasileira de Plantas Medicinais. 2014 [cited 2018 Mar 03]; 16(3): 566-573. Available from: http://www.scielo.br/scielo.php?pid=S151605722014000300014\&script=sci_abstract\&tlng=pt

[18] Fonseca MCM, Casali VWD, Cecon PR. Efeito de aplicação única dos preparados homeopáticos Calcarea carbonica, Kalium phosphoricum, Magnesium carbonicum, Natrium muriaticum e Silicea terra no teor de tanino em Porophyllum ruderale (Jacq.) Cassini. Cultura Homeopática. 2006; 1(14):6-8.

[19] Andrade FMC, Casali VWD, Cecon PRC. Crescimento e produção de cumarina em plantas de chambá (Justicia pectoralis Jacq.) tratadas com isoterápico. Revista Brasileira Plantas Medicinais. 2012 [cited 2018 Jun 20]; 14: 154-158. Available from: http://www.scielo.br/pdf/rbpm/v14nspe/05.pdf

[20] Brasil. Farmacopeia homeopática brasileira. 3. ed. São Paulo: Andrei. 2011 [cited 2017 Ago 20]. Available from: http://portal.anvisa.gov.br/farmacopeia-homeopatica

[21] R Core Team R: A language and environment for statistical computing. R Foundation for Statistical Computing, Vienna, Austria. 2017 [cited 2017 Ago 20]. Available from: https://www.R-project.org/

[22] Tichavský R. Homeopatía para las plantas. Monterrey, Nuevo Leon: Fujimoto, Centro Universitario Comenius, 2009.

[23] Bonato L, Silva EP. Effect of the homeopathic solution Sulphur on the growth and productivity of radish. Acta Scientiarum Agronomy. 2003 [cited 2019 Jul 12]; 25(2): 259263. Available from:

http://periodicos.uem.br/ojs/index.php/ActaSciAgron/article/view/1758/1586

Received: 14 Apr, 2019. Accepted: 21 Aug, 2019.

(C) International Journal of High Dilution Research.

Not for commercial purposes. 